\title{
P2X7-Like Receptor Activation in Astrocytes Increases Chemokine Monocyte Chemoattractant Protein-1 Expression via Mitogen- Activated Protein Kinase
}

\author{
William Panenka, ${ }^{1}$ Humberto Jijon, ${ }^{1}$ Leonie M. Herx, ${ }^{1}$ John N. Armstrong, ${ }^{1}$ Denise Feighan, ${ }^{1}$ Tao Wei, ${ }^{2}$ \\ V. Wee Yong, ${ }^{1}$ Richard M. Ransohoff, ${ }^{2}$ and Brian A. MacVicar ${ }^{1}$ \\ ${ }^{1}$ Neuroscience Research Group, University of Calgary, Calgary, Alberta, Canada T2N 4N1, and 2Department of \\ Neuroscience, The Lerner Research Institute, Cleveland Clinic Foundation, Cleveland, Ohio 44195
}

Leukocyte infiltration in the CNS after trauma or inflammation is triggered in part by upregulation of the chemokine, monocyte chemoattractant protein-1 (MCP-1), in astrocytes. However the signals that induce the upregulation of MCP-1 in astrocytes are unknown. We have investigated the roles for ATP P2X7 receptor activation because ATP is an intercellular signaling transmitter that is released in both trauma and inflammation and P2X7 receptors are involved in immune system signaling. Astrocytes in primary cell culture and acutely isolated from the hippocampus were immunopositive for P2X7 receptors. In astrocyte cultures, application of the selective P2X7 agonist, benzoylbenzoyl ATP (Bz-ATP), activated MAP kinases extracellular signal receptor-activated kinase 1 (ERK1), ERK2, and p38. Purinergic antagonists depressed this activation with a profile suggesting P2X7 receptors. Bz-ATP also increased MCP-1 expression in cultured astrocytes, and again P2X7 antagonists prevented this increase. Blocking either the ERK1/ERK2 or the

Trauma and ischemia in the CNS selectively increase the expression of a chemokine, monocyte chemoattractant protein-1 (MCP1), in astrocytes (Wang et al., 1995; Berman et al., 1996). MCP-1 is a member of the CC family of chemokines and activates CCR2 receptors on monocytes (Rollins, 1996; Ransohoff and Tani, 1998). Increased MCP-1 expression is an early step in the inflammatory response in neural tissue and is critical in promoting the invasion of inflammatory monocytes into the brain (Rollins, 1996; Lassmann, 1997; Ransohoff and Tani, 1998; Weiss et al., 1999). MCP-1 is also thought to be involved in the pathogenesis of several diseases. For example, in multiple sclerosis, MCP-1 is localized to astrocytes in scars and in surrounding tissue (McManus et al., 1998; Simpson et al., 1998). In an animal model of multiple sclerosis, experimental allergic encephalomyelitis, passive immunization with anti-MCP-1 antibodies reduces disease progression (Kennedy et al., 1998). There may be a role for astrocyte production of MCP-1 in human immunodeficiency virus (HIV) as well because HIV-1 Tat-stimulated astrocytes pro-

Received Jan. 22, 2001; revised July 6, 2001; accepted July 9, 2001.

This work was supported by the Canadian Institutes for Health Research (CIHR) and the National Institutes of Health (Grant 2RO1-NS32151 to R.M.R.). B.A.M. is a CIHR Senior Scientist and an Alberta Heritage Foundation for Medical Research Scientist. We thank Dr. Brent Winston for his insight and technical help and Kirk Whalen for technical assistance.

Correspondence should be addressed to Brian A. MacVicar, Department of Physiology and Biophysics, Faculty of Medicine, University of Calgary, Calgary, Alberta, Canada T2N 4N1. E-mail: macvicar@ucalgary.ca.

Copyright (C) 2001 Society for Neuroscience $\quad 0270-6474 / 01 / 217135-08 \$ 15.00 / 0$ p38 pathway (with PD98059 or SB203580, respectively) significantly inhibited Bz-ATP-induced MCP-1 expression. Coapplication of both antagonists caused a greater depression. We also tested the roles for ATP receptor activation in inducing MCP-1 upregulation in corticectomy, an in vivo model of trauma. This model of cortical trauma was previously shown to increase MCP-1 expression in vivo principally in astrocytes. Suramin, a wide-spectrum purinergic receptor antagonist, significantly depressed the rapid ( $3 \mathrm{hr}$ ) trauma-induced increase in MCP-1 mRNA. These data indicate that purinergic transmitter receptors in astrocytes are important in regulating chemokine synthesis. The regulation of MCP-1 in astrocytes by ATP may be important in mediating communication with hematopoietic inflammatory cells.

Key words: purinergic receptors; MAP kinase; ERK1; ERK2; p38; P2X7; P2Z; ATP; Bz-ATP; chemokine; MCP-1; astrocyte duce MCP-1, and MCP-1 is elevated in the CSF of patients with acquired immunodeficiency syndrome (AIDS) dementia (Conant et al., 1998; Weiss et al., 1999). Therefore, understanding the regulation of MCP-1 expression could provide tools for manipulating inflammation of the CNS.

In the absence of damage or inflammation, MCP- 1 mRNA is normally not found in the CNS. However, after ischemic, mechanical, or cryogenic trauma to cortical tissue, there is rapid expression of MCP-1 mRNA as detected by RT-PCR or in situ hybridization (Wang et al., 1995; Berman et al., 1996; Glabinski et al., 1996; Ivacko et al., 1997). This increase precedes and is thought to promote the invasion of monocytes and inflammation in ischemic tissue (Yamagami et al., 1999). Astrocytes have been shown to be the principal cell expressing MCP-1 after both ischemia and trauma (Berman et al., 1996; Glabinski et al., 1996; Gourmala et al., 1997). Although the signaling mechanisms that lead to MCP-1 expression in astrocytes are unknown, it is possible that the astrocytes respond to a factor released from surrounding neurons. We have investigated the roles for purinergic receptor activation in astrocytes in regulating $\mathrm{MCP}-1$ expression because high levels of ATP are released during trauma and ischemia (Rudolfi, 1994; Braun et al., 1998) and astrocytes express a number of purinergic receptors (Barnard et al., 1997).

We discovered that in primary astrocyte cultures, activation of the purinergic $\mathrm{P} 2 \mathrm{X} 7$ receptor leads to the activation of the MAP kinases ERK1, ERK2, and p38 as measured by Western blotting and in vitro kinase assays. Activation of $\mathrm{P} 2 \mathrm{X} 7$ receptors on cul- 
tured astrocytes also resulted in MCP-1 mRNA accumulation. Either purinergic or MAP kinase antagonists blocked the P2X7 receptor-mediated increase in MCP-1 expression. Finally we used an in vivo neurotrauma model, rat corticectomy, to show that the MCP-1 increase in damaged neuronal tissue was blocked by a purinergic receptor antagonist. These data show that purinergic transmitter receptors in astrocytes are important signals in controlling chemokine expression. This pathway could be important in mediating communication with hematopoietic inflammatory cells.

\section{MATERIALS AND METHODS}

Cell culture. Astrocyte cultures were prepared from $1 \mathrm{~d}$ postnatal Sprague Dawley rats using modifications of standard techniques (Merrill et al., 1984; MacVicar et al., 1991). All procedures conformed to Canadian Council on Animal Care guidelines. Briefly, cortical tissue was dissociated by trituration, and the suspension was plated onto glass coverslips and grown in DMEM and Ham's F-12 (1:1) with 10\% FCS. For experimental measurements in cell culture, astrocyte cultures were plated in equal numbers into six-well plates and allowed to grow to confluency. Once confluent, the medium was switched to DMEM with $0.5 \%$ FCS for 48-72 hr to reduce the background MAP kinase activation. After the period of serum starvation, the test compounds were added to the cultures. In control experiments, vehicle alone (either 1/1000 DMSO or $\mathrm{H}_{2} \mathrm{O}$ ) was added to matched cultures in the same six-well plate for an equivalent time period. After stimulation, the medium was removed, and the cells were processed for further study.

Western immunoblotting. Protein extraction and Western blots were performed as previously described (Crepel et al., 1998) using the following antibodies (all from New England Biolabs, Beverly, MA): antiphosphospecific MAP kinase (1/1000), anti-phospho-p38 (1/1000), and anti-p38 (1/1000). Secondary antibody was anti-rabbit IgG, HRP-linked $(\mathrm{H}+\mathrm{L})$ whole antibody (1/3000; Amersham Pharmacia Biotech, Arlington Heights, IL), and for detection we used ECL Plus+ (Amersham Pharmacia Biotech).

ERK activity assays. ERK catalytic assays were performed according to the method described by Winston and Riches (1995). This assay measures phosphotransfer by the ERKs onto a substrate peptide corresponding to residues 663-673 of the epidermal growth factor receptor (EGFR). This EGFR peptide assay offers a selectivity advantage over the classic myelin basic protein (MBP) substrate assay. MBP is phosphorylated by a variety of kinases, including the ERKs, PKC, calciumcalmodulin dependent kinases, and PKA (Heasley and Johnson, 1992), whereas the EGFR peptide is phosphorylated selectively by the ERKs. Notably, the EGFR is also an in vivo substrate of the ERKs (Winston and Riches, 1995). After protein determination, $20 \mu \mathrm{l}$ supernatant samples were mixed with $20 \mu \mathrm{l}$ of a reaction buffer consisting of $50 \mathrm{~mm}$ $\beta$-glycerophosphate, $100 \mu \mathrm{M} \mathrm{NaVO}, 20 \mathrm{mM} \mathrm{MgCl}_{2}, 200 \mu \mathrm{M}$ ATP, 10 $\mu \mathrm{g} / \mathrm{ml}$ PKA inhibitor (PKI), $1 \mathrm{~mm}$ EGTA, $1 \mu \mathrm{g}$ EGFR peptide, and 1 $\mu \mathrm{Ci}\left[\gamma_{-}{ }^{32} \mathrm{P}\right] \mathrm{ATP}$. This mixture was incubated at $32^{\circ} \mathrm{C}$ for $15 \mathrm{~min}$ and stopped with the addition of $10 \mu \mathrm{l}$ of $25 \%$ (w/v) TCA. Then, $40 \mu \mathrm{l}$ of this mixture was spotted onto $\mathrm{p} 81$ filter paper and washed four times in 75 mM phosphoric acid and one time in acetone. After drying, samples were counted on a beta counter.

Immunocytochemistry. Astrocyte cultures were grown on polyornithine-coated glass coverslips and fixed with $4 \%$ paraformaldehyde in $0.1 \mathrm{M}$ phosphate buffer $\left(4^{\circ} \mathrm{C}, 15 \mathrm{~min}\right)$, rinsed in PBS, and preincubated for $1 \mathrm{hr}$ in PBS containing 5\% normal donkey serum. Alternatively, astrocytes were acutely isolated from hippocampus and attached to polyornithine-coated coverslips using our previously described techniques (Tse et al., 1992; Fraser et al., 1995). Briefly, hippocampal slices (400 $\mathrm{mm}$ ) were prepared from 3-week-old rats and were immediately transferred to a stirring chamber containing artificial CSF with papain. After $40 \mathrm{~min}$, cells were isolated by mechanical trituration of individual brain slices. Cells were adhered to the coverslip by brief spinning in a centrifuge. The acutely isolated astrocytes were fixed and stained with the identical protocol as the cultured cells. Coverslips were incubated overnight $\left(4^{\circ} \mathrm{C}\right)$ in PBS containing $0.005 \%$ BSA, rabbit anti-MCP1 (1:3000; Serotec, Indianapolis, IN) or rabbit anti-P2X7 (1:3000; Alamone Labs, Jerusalem, Israel), and mouse anti-GFAP (1:5000; PharMingen, San Diego, CA), rinsed and incubated overnight $\left(4^{\circ} \mathrm{C}\right)$ with $\mathrm{Cy}^{2}$-conjugated donkey anti-mouse $\mathrm{IgG}$ and $\mathrm{Cy}^{3}$-conjugated donkey anti-rabbit IgG (1:1000; Jackson ImmunoResearch, West Grove, PA). Coverslips were mounted with FluorSave (Calbiochem, La Jolla, CA) and imaged on an LSM510 attached to an Axioplan 2 upright microscope (Zeiss, Oberkochen, Germany).

ELISA analysis of MCP-1 protein expression. Cells were seeded in 96-well ELISA plates (Biosource, Camarillo, CA) at constant density of 50,000 cells per well in $200 \mu \mathrm{l}$ of media per well. The plating and initial growth media were identical to those listed above for growing astrocytes in cell culture. After $3 \mathrm{~d}$, the medium was changed to DMEM with $0.5 \%$ FCS $24 \mathrm{hr}$ before the experiments to reduce background activation of cells. Benzoyl-benzoyl ATP (Bz-ATP) $(100 \mu \mathrm{M})$ or an equivalent volume of $\mathrm{H}_{2} \mathrm{O}$ (as a control) was added to matched wells at specified times. The $\mathrm{MCP}-1$ production in wells was measured according to the manufacturer's specifications and was normalized to the values recorded in timematched control wells.

$R N A$ extraction, $R T-P C R$, and fluorescence-based real-time quantitation of MCP-1 transcripts. Samples were dissolved in Trizol to extract total RNA. Samples were analyzed using either RT-PCR or fluorescencebased real-time quantitation of MCP-1 transcripts as previously described (McTigue et al., 1998; Schreiber et al., 2001). Briefly, samples were ethanol precipitated, the pellets were dissolved in $100 \mu$ l of RNasefree $\mathrm{H}_{2} \mathrm{O}$, and RNA concentration was determined spectrophotometrically. Then, RT-PCR dot-blot hybridization analysis was performed. PCR products were denatured, transferred to nylon membranes, and hybridized with nick-translated cDNA inserts. Hybridization signals were quantified by Phosphoimager (Molecular Dynamics, Sunnyvale, CA) using a blinded protocol.

Reverse transcription. One microgram of RNA was treated with DNase according to the manufacturer's instructions (Life Technologies, Gaithersburg, MD). First strand cDNA was synthesized using $1 \mathrm{mg}$ of DNasetreated RNA, oligo dT primers, and SuperScript IITM. Amplified PCR products of $\alpha$-tubulin transcripts were analyzed on ethidium bromidestained agarose gels to confirm the presence of intact RNA in all samples and verify that, in each sample, the cDNA synthesis reaction generated products capable of being amplified in the PCR.

Optimization of PCR conditions and generation of standard curves. A fragment of the rat MCP-1 transcript $(\sim 400 \mathrm{bp})$ was amplified in RTPCR reactions using gene specific primers (5'CCTGTTGTTCACAGTTGCTGCC3' and 3'TCTACAGAACTGCTTGACGGTGGTTG5'). The product of this reaction was purified (PCR Purification Kit; Qiagen, Valencia, CA), and the concentration of the amplified fragment was quantitated by spectrophotometry. Five serial 10 -fold dilutions of this fragment (from $2 \mathrm{pg} / \mathrm{ml}$ to $0.2 \mathrm{fg} / \mathrm{ml}$ ) were prepared, amplified by PCR, and labeled with SYBR Green (Roche, Indianapolis, IN), which yields a bright fluorescence on binding to double-stranded nucleic acids; this fluorescence abruptly diminishes on denaturation of DNA strands during melting-curve analysis. PCR and analysis to generate standard curves were performed in $20 \mu \mathrm{l}$ reactions in glass capillaries, using a LightCycler (Roche) and LightCycler3 software, according to the manufacturer's instructions. For each reaction, melting curve analysis was used to detect the synthesis of nonspecific products. Negative controls (omitting input cDNA) were also used in each PCR run to confirm the specificity of PCR products. To optimize PCR conditions, standard curve reactions were performed at varying annealing temperatures, $\mathrm{Mg}^{2+}$ concentrations, with or without FastStart (Roche). At optimal conditions for PCR, standard curves were linear across serial 10 -fold dilutions, and the melting curve analysis indicated synthesis of a single homogeneous product of expected melting temperature.

PCR and real-time analysis. Standard curves were generated with each set of samples. The PCR reaction in $20 \mu \mathrm{l}$ contained $2 \mathrm{mM} \mathrm{Mg}^{2+}, 0.25 \mu \mathrm{M}$ each of forward and reverse primer (identical to those used to generate the template for standard curves), $1 \times$ FastStart DNA Master SYBR Green I (Roche) containing Taq DNA polymerase, and $2 \mu \mathrm{l}$ of cDNA synthesis reaction product. Reaction conditions for PCR were as follows: denaturation at $95^{\circ} \mathrm{C}$ for $7 \mathrm{~min}, 40$ cycles of amplification by denaturing at $95^{\circ} \mathrm{C}$ for $15 \mathrm{sec}$, annealing at $60^{\circ} \mathrm{C}$ for $5 \mathrm{sec}$, extending at $72^{\circ} \mathrm{C}$ for 15 sec. The accumulation of products was monitored by SYBR Green fluorescence at completion of each cycle. Analysis was performed on LightCycler3 software, and results are expressed as the crossing point at which accumulation of PCR products became exponential. Using the standard curve, this value was converted to picograms per milliliter. Reaction conditions for melting curve analysis were as follows: denaturation to $95^{\circ} \mathrm{C}$ at $20^{\circ} \mathrm{C} / \mathrm{sec}$ without plateau phase, annealing at $65^{\circ} \mathrm{C}$ for 15 sec, denaturation to $95^{\circ} \mathrm{C}$ at $0.1^{\circ} \mathrm{C} / \mathrm{sec}$, with continuous monitoring of SYBR Green fluorescence.

Corticectomy. A $12-15 \mathrm{~mm}^{3}$ volume of parietal-occipital cortex was 

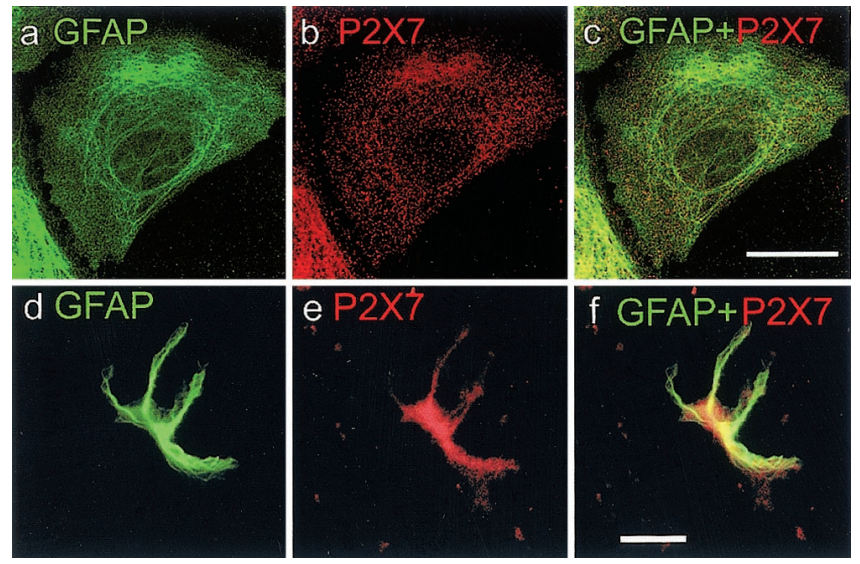

Figure 1. The $\mathrm{P} 2 \mathrm{X} 7$ receptor is present in rat cortical astrocyte cultures. Astrocytes were confirmed to be the predominant cell type $(>95 \%)$ in our cultures as indicated by positive staining for the astrocyte-specific marker glial fibrillary acid protein (GFAP) ( green) as seen in $a$ and $d$. The $\mathrm{P} 2 \mathrm{X} 7$ receptor is expressed in cultured $(a)$ and acutely isolated $(d)$ astrocytes as evidenced by positive immunostaining with $\mathrm{P} 2 \mathrm{X} 7$ receptor antibody (red) in $b$ and $e$. Colocalization of GFAP and P2X7 is indicated by double staining in $c$ and $f$. Note that immunocytochemistry indicated that all GFAP-positive cultured astrocytes also expressed the P2X7 receptor. Scale bars: $a-c, 20 \mu \mathrm{m} ; d-f, 20 \mu \mathrm{m}$.

removed by aspiration as a model of CNS trauma as previously described (Balasingam and Yong, 1996). Neurosurgeons routinely perform similar procedures for the resection of brain tumors, epileptic foci, etc. This corticectomy allows the local delivery of compounds to the injury site. Briefly, adult male rats were anesthetized (ketamine, $40 \mathrm{mg} / \mathrm{kg}$; and xylazine, $7 \mathrm{mg} / \mathrm{kg}$, i.p.) and immobilized in a stereotaxic frame. A midline incision was made, followed by a unilateral circular (diameter, 2 $\mathrm{mm}$ ) craniectomy over the left hemisphere, $1 \mathrm{~mm}$ lateral of the midline and midway between lambda and bregma. Preceding removal of the dura, the cortex was aspirated down to the corpus callosum (ventral aspect). Gelfoam $\left(2 \mathrm{~mm}^{3}\right)$ was soaked in Suramin (Research Biochemicals, Natick, MA) or saline control, and applied over the corticectomy site (Balasingam and Yong, 1996). After 3 hr, animals were decapitated, and tissue surrounding the lesion site was collected.

Statistical analysis. Raw data in the form of scintillation counts for the MAP kinase assays or Phosphoimager densitometry units for PCR from separate cultures were subjected to the Freidman two-way ANOVA by ranks. When the significance of the obtained $F$ value was $<0.05$, multiple comparisons were made against the control or Bz-ATP-stimulated group using a one-tailed Wilcoxon sign rank test. In all cases, a $p$ value of 0.05 or less was considered significant and is indicated on the appropriate figures with an asterisk. Error bars in all figures represent SE. Alternatively, the MCP-1/GAPDH mRNA ratios were analyzed by ANOVA using SPSS for Windows. Significance is described in the text.

\section{RESULTS}

\section{The P2X7 receptor activates ERK1/ERK2 and p38}

Although functional studies suggest that the $\mathrm{P} 2 \mathrm{X} 7$ receptors are expressed in astrocytes (Ballerini et al., 1996), there is no anatomical evidence. Retinal Muller cells have been shown to express P2X7 receptors (Pannicke et al., 2000). We examined the immunoreactivity of astrocytes to an antibody against the P2X7 receptor. In primary cell culture, immunostaining with anti-P2X7 receptor antibody demonstrated that most of the GFAP-positive astrocytes were immunopositive for $\mathrm{P} 2 \mathrm{X} 7$ receptors (Fig. $1 a-c$ ). Punctate P2X7 receptor immunoreactivity was observed over the entire cellular membrane of GFAP-immunoreactive astrocytes. We also examined the immunoreactivity of astrocytes acutely isolated from hippocampal slices that were fixed to coverslips immediately after isolation. Astrocytes were identified by their a
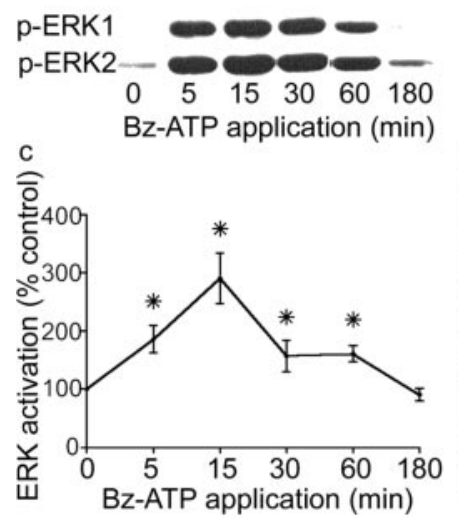

b
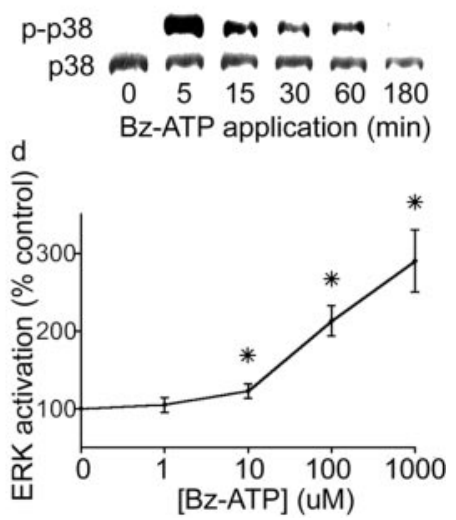

Figure 2. Bz-ATP, a $\mathrm{P} 2 \mathrm{X} 7$ receptor agonist, activates the MAP kinases ER1/ERK2 and p38. $a-c$, Rat cortical astrocytes were treated with $100 \mu \mathrm{M}$ $\mathrm{P} 2 \mathrm{X} 7$ receptor-specific agonist benzoyl-benzoyl ATP $(B z-A T P)$ for the time periods indicated. $a$, Western blotting with phospho-specific ERK antibody indicated an increase in the active, phosphorylated form of the ERK proteins. $b$, Phospho-specific p38 antibody indicated an increase in the active, phosphorylated form of p38 after $100 \mu \mathrm{M} \mathrm{Bz}-\mathrm{ATP}$ application. Parallel blotting with p38 antibody indicated equal protein loading between lanes. $c$, ERK1/ERK2 activity assay confirmed the increased activity of the ERKs in response to Bz-ATP. $d$, The dose-response curve of Bz-ATP-induced ERK1/ERK2 activity demonstrates that activity increased markedly between 10 and $100 \mu \mathrm{M}$ and continued to increase up to $1000 \mu \mathrm{M}$, the highest concentration tested. Note that time of application for the various concentrations was held constant at $15 \mathrm{~min}$. The asterisks indicate a significant increase from the control group.

stellate morphology and GFAP immunoreactivity and were observed to be immunopositive for the P2X7 receptor (Fig. $1 d-f$ ).

Little is known about the signaling pathways downstream of $\mathrm{P} 2 \mathrm{X} 7$ receptor activation in astrocytes. Immunoblotting with phosphospecific antibodies to ERK1, ERK2, and p38 demonstrated that all three MAP kinases were activated in cultures that were treated with the specific $\mathrm{P} 2 \mathrm{X} 7$ receptor agonist Bz-ATP (Fig. 2a,b). Application of Bz-ATP caused a rapid and reversible increase in phosphorylated ERK1, ERK2, and p38 within 5-15 min that subsided within $3 \mathrm{hr}$. Using an ERK in vitro kinase assay (Winston and Riches, 1995), we also measured a dose-dependent increase in MAP kinase activity after Bz-ATP application (Fig. $2 c, d)$.

The classification of a purinergic receptor subtype involves the analysis of potency of several agonists and antagonists (Chen et al., 1995). We therefore compared a number of purinergic receptor agonists with respect to their ability to activate ERK1/ERK2 (Fig. 3a). ATP strongly activates a variety of purinergic receptors, many of which have been linked to ERK1/ERK2 activation (Neary and Zhu, 1994; Swanson et al., 1998). Therefore, it was not surprising that ATP activated ERK1/ERK2 in our astrocyte cultures. ADP is a weak agonist of the $\mathrm{P} 2 \mathrm{X} 7$ receptor and produced a lesser increase in ERK1/ERK2 activation compared with Bz-ATP when applied to cultured astrocytes. AMP and adenosine are agonists at other purinergic receptor subtypes but are not agonists at the $\mathrm{P} 2 \mathrm{X} 7$ receptor. Neither AMP nor adenosine stimulated the ERKs. Adenosine 5'-O-[3-thiotriphosphate] $(\mathrm{ATP}-\gamma-\mathrm{S})$ is a nonhydrolyzable ATP analog that weakly activates the P2X7 receptor (Surprenant et al., 1996). ATP- $\gamma-\mathrm{S}$ activated ERK1/ERK2 to a smaller extent than did Bz-ATP. $\alpha-\beta$ Methyl ATP is predominantly a P2X1-receptor agonist, whereas 2-methyl-thio-ATP (2-MS-ATP) is a P2X3-receptor agonist (Watson and Girdlestone, 1996). Both had significantly less effect 
Figure 3. Purinergic receptor agonists and antagonists confirm that the $\mathrm{P} 2 \mathrm{X} 7$ receptor activates the ERKs. $a$, Purinergic agonists demonstrated a profile consistent with P2X7 receptor-induced ERK activation. $A T P-\gamma-S$, Adenosine 5'-O-[3-thiotriphosphate]; 2-MS-ATP, 2-methyl-thio-ATP; $\alpha-\beta$ $M$-ATP, $\alpha-\beta$-methylene ATP. The control level is the level of MAP kinase activation in untreated cultures and was defined as $0 \%$. The level of ERK activation documented with the selective $\mathrm{P} 2 \mathrm{X} 7$ receptor agonist Bz-ATP was defined as $100 \%$. All compounds were applied for $15 \mathrm{~min}$ at a concentration of $100 \mu \mathrm{M}$. $b$, Purinergic receptor antagonists and the ERK antagonist PD98059 diminished ERK activation in response to $\mathrm{P} 2 \mathrm{X} 7$ receptor stimulation. All

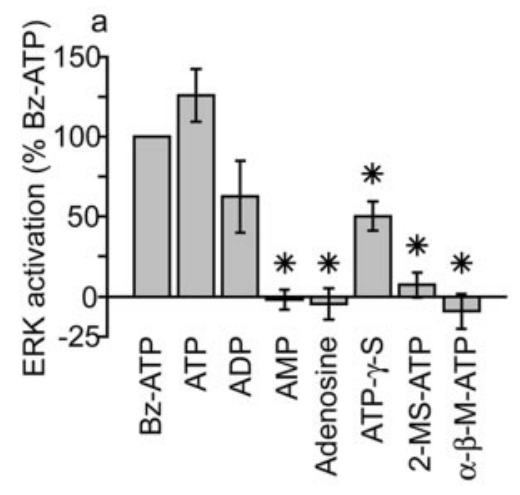

b

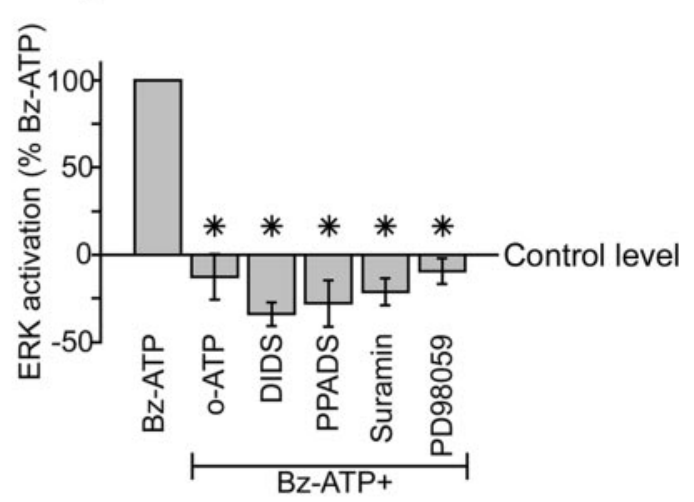

cultures were subjected to $15 \mathrm{~min}$ of $100 \mu \mathrm{M}$ Bz-ATP stimulation in the presence or absence of various signaling inhibitors. Concentrations and preincubation (PI) times of inhibitors were as follows: PD98059, $50 \mu \mathrm{M}, 15 \mathrm{~min}$ PI; o-ATP, $300 \mu \mathrm{M}, 2 \mathrm{hr}$ PI; DIDS, $200 \mu \mathrm{M}, 2 \mathrm{hr}$ PI; PPADS, $100 \mu \mathrm{M}$, 15 min PI; Suramin, $1 \mathrm{~mm}, 15 \mathrm{~min}$ PI. o-ATP, Oxidized ATP; PPADS, pyridoxalphosphate-6-azophenyl-2',4'-disulfonic acid; DIDS, 4',4'diisothiocyanatostilbene-2,2'-disulfonic acid. Asterisks indicate a significant decrease from the Bz-ATP sample group.

than Bz-ATP on ERK (Fig. 3a). These results indicated that the observed increase in ERK activity in response to Bz-ATP is likely a $\mathrm{P} 2 \mathrm{X} 7$ receptor-mediated event.

Next, we tested whether a variety of purinergic receptor antagonists (Fig. 3b) could block Bz-ATP activation of ERK1/ERK2. Bz-ATP mediated ERK activation was significantly blocked by $4^{\prime}, 4^{\prime}$-diisothiocyanatostilbene-2,2'-disulfonic acid (DIDS), an ion channel blocker that has been shown to inhibit P2X7-mediated responses (el-Moatassim and Dubyak, 1993). The general P2Xreceptor antagonist, pyridoxalphosphate-6-azophenyl-2',4'-disulphonic acid (PPADS) (North and Barnard, 1997), and the nonselective P2X/P2Y-receptor antagonist, Suramin (Wiley et al., 1993), also depressed the Bz-ATP activation of the ERKs. It should be noted that PPADS also inhibits P2Y1 receptors (Ralevic and Burnstock, 1998). Application of oxidized ATP (oATP), a specific and irreversible $\mathrm{P} 2 \mathrm{X} 7$ receptor antagonist (Murgia et al., 1993; but see Beigi and Dubyak, 2000), blocked activation of the ERKs to an extent equivalent to the more general purinergic antagonists. Because the level of ERK attenuation induced by the general purinergic antagonists was similar to the level of ERK activation induced by the P2X7 specific inhibitor o-ATP, we can conclude that the Bz-ATP effect is dependent on activation of the $\mathrm{P} 2 \mathrm{X} 7$ receptors. These data form a pharmacological profile consistent with other descriptions of P2X7-mediated events (Ballerini et al., 1996; Lammas et al., 1997).

\section{MCP-1 expression is induced by $\mathrm{P} 2 \mathrm{X} 7$ receptor activation in astrocytes}

We next examined the expression of MCP-1 mRNA after BzATP application to determine whether $\mathrm{P} 2 \mathrm{X} 7$ receptor activation was involved in MCP-1 production. Bz-ATP increased MCP-1 mRNA synthesis in primary cell cultures of astrocytes, and the properties of MCP-1 induction by Bz-ATP are depicted in Figure $4, a$ and $b$. Maximal and significant $(p<0.05)$ MCP-1 mRNA accumulation occurred between 1 and $2 \mathrm{hr}$ after Bz-ATP exposure (Fig. 4a). The dose-response curve of Bz-ATP-induced MCP-1 mRNA expression was similar to that seen for Bz-ATPinduced MAP kinase activity because MCP-1 mRNA production was significantly elevated at $10 \mu \mathrm{M}$ and was maximal at $100 \mu \mathrm{M}$ (Fig. $4 b$ ). The apparent $\mathrm{EC}_{50}$ was $40 \mu \mathrm{M}$. ELISA results indicated that MCP-1 protein levels also increased after Bz-ATP exposure (Fig. 4c).
As mentioned above, these cultures were $>95 \%$ astrocytes as judged by immunocytochemistry. However, we wished to ensure that the MCP-1 expressing cells were indeed GFAP-positive astrocytes because microglial cells can also express MCP-1. To establish that the MCP-1 expression in cell culture was actually in astrocytes, we used simultaneous immunohistochemical staining for GFAP and MCP-1. Figure 5 demonstrates that GFAPimmunoreactive astrocytes (Fig. $5 a$ ) were also immunoreactive for MCP-1 (Fig. 5b).

To establish that the MCP-1 expression was a $\mathrm{P} 2 \mathrm{X} 7$ receptormediated event, we used the same strategy and compounds used above in describing the link between P2X7 and MAP kinase. Figure $6 a$ is evidently similar to Figure $3 a$. Rank potency in inducing MCP-1 mRNA expression was found to be Bz-ATP > $\mathrm{ATP}>\mathrm{ADP}>\mathrm{AMP}=$ adenosine. The other $\mathrm{P} 2 \mathrm{X}$ receptor agonists also produced a profile consistent with a $\mathrm{P} 2 \mathrm{X} 7$ receptormediated effect because ATP- $\gamma$-S and 2-MS-ATP induced an intermediate response and $\alpha$ - $\beta$-M-ATP showed little efficacy in inducing MCP-1 mRNA accumulation. Figure $6 b$ demonstrates that P2X7-induced MCP-1 expression was sensitive to purinergic receptor antagonists. Rank potency of inhibition was Suramin $>$ PPADS > DIDS (Fig. 6b).

Blocking either the ERK1/ERK2 or the p38 pathway (with PD98059 or SB203580, respectively) inhibited Bz-ATP-induced MCP-1 expression (Fig. 6c). Application of both the ERK and p38 inhibitors resulted in a slightly greater depression of MCP-1. These results indicated that both ERK and p38 can regulate MCP-1 expression.

\section{In vivo MCP-1 expression involves purinergic receptors}

We used a rat corticectomy model to determine the role for purinergic receptor activation in $\mathrm{MCP}-1$ expression in vivo. Corticectomy significantly increased the expression of MCP-1 in tissue that was harvested from the cortical region surrounding the lesion [MCP-1/GAPDH was $0.16 \pm 0.06$ in control $(n=4)$ versus $11.55 \pm 3.46$ in the lesion $(n=4) ; p<0.001]$. Previous studies have shown that the increased MCP-1 in this model is selectively expressed in GFAP-positive astrocytes (Glabinski et al., 1996). The purinergic receptor inhibitor Suramin significantly attenuated MCP-1 expression in response to corticectomy (MCP-1/ GAPDH $1.88 \pm 0.60 ; n=4 ; p<0.05)$, indicating that purinergic receptors are involved in CNS MCP-1 expression (Fig. 7). 

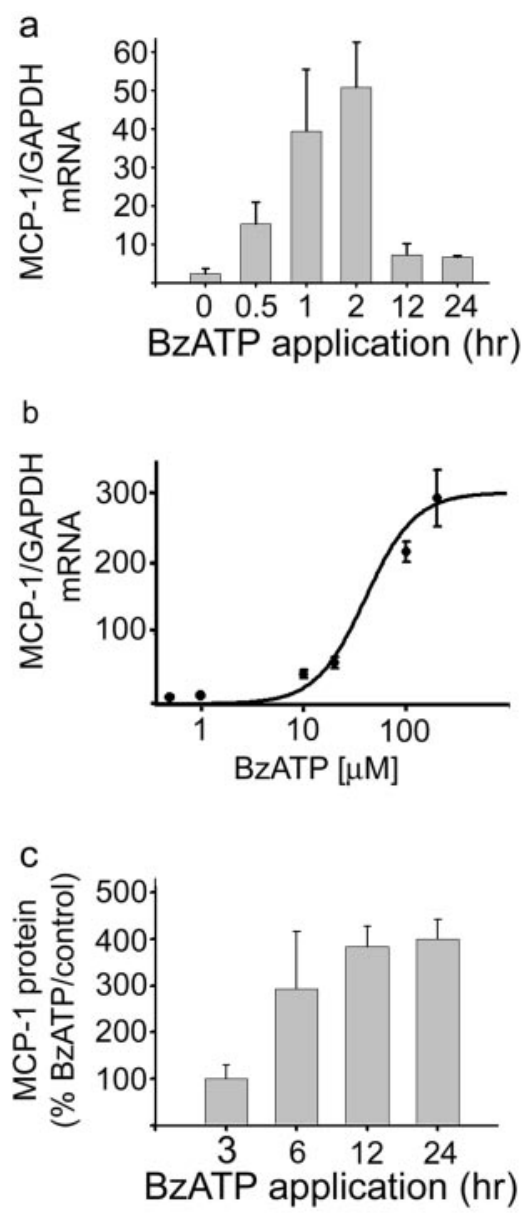

Figure 4. Bz-ATP, a $\mathrm{P} 2 \mathrm{X} 7$ receptor agonist, induces expression of the chemokine MCP-1. $a$, MCP-1 expression was upregulated by $\mathrm{P} 2 \mathrm{X} 7$ receptor stimulation. Cultured astrocytes were treated with $100 \mu \mathrm{M}$ P2X7 receptor-specific agonist Bz-ATP for the time periods indicated, followed by analysis using fluorescence-based real-time quantitation of MCP-1 transcripts for MCP-1 mRNA. Values are expressed relative to GAPDH mRNA levels. $b$, The dose-response curve of Bz-ATP induced MCP-1 upregulation demonstrated that MCP-1 expression increased markedly between 10 and $100 \mu \mathrm{M} \mathrm{Bz}$-ATP with $\mathrm{EC}_{50}$ of $\sim 40 \mu \mathrm{M}$. The time of application for the various concentrations was held constant at $2 \mathrm{hr}$. $c$, ELISA analysis indicated that Bz-ATP application $(100 \mu \mathrm{M})$ increased the level of MCP-1 protein produced by astrocytes in primary culture. The values were expressed relative to matched controls in which vehicle was added for the same time period $(n=3)$.

\section{DISCUSSION}

This paper provides evidence for the involvement of astrocyte $\mathrm{P} 2 \mathrm{X} 7$ receptors in mediating the increase in the expression of MCP-1 that has previously been observed in astrocytes (Glabinski et al., 1996). We have shown that astrocytes express P2X7 receptors and that activation of these receptors increases expression of the chemokine, MCP-1. The activation of the MAP kinases, ERK1/2 and p38, by $\mathrm{P} 2 \mathrm{X} 7$ receptor stimulation is a critical step in increased MCP-1 expression. We provide evidence that this pathway is activated during cortical trauma, because a purinergic receptor antagonist also blocked corticectomy-induced MCP-1 expression. This response to activation of astrocyte P2X7 receptors may be an integral component of the inflammatory response in the brain.

Trauma to the CNS triggers a cascade of reactions leading to the production of inflammatory infiltrate. MCP-1 is the predom-
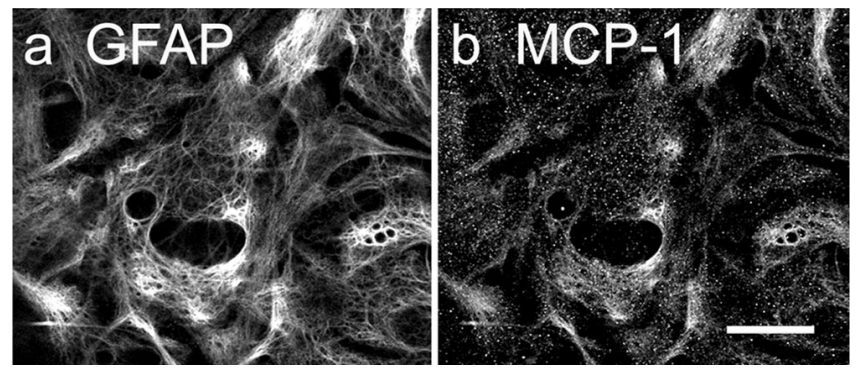

Figure 5. Rat cortical astrocyte cultures express the chemokine monocyte chemoattractant protein-1 (MCP-1). $a$ illustrates immunostaining for the astrocyte specific marker glial fibrillary acidic protein (GFAP). Cultured astrocytes also expressed MCP-1 as seen by immunostaining with MCP-1 antibody $(b)$. Scale bar, $20 \mu \mathrm{m}$.

inant chemokine upregulated after CNS trauma. MCP-1 is a monocyte chemoattractant that leads to the characteristic monocyte-rich infiltrate (Ransohoff and Tani, 1998) observed after injury. A number of studies support the central role of MCP-1 in inflammation. Transgenic mice overexpressing glialspecific MCP-1 show pronounced monocyte and macrophage infiltrate (Fuentes et al., 1995). In a study of intrahippocampal injections of various chemokines, MCP-1 was found to be the most potent stimulus of monocyte recruitment to the site of injection (Bell et al., 1996). The importance of MCP-1 in inducing inflammation is also highlighted by genetic studies in which MCP-1 knockout mice showed striking deficits in monocyte recruitment ( $\mathrm{Gu}$ et al., 1998; Gosling et al., 1999). Functional studies demonstrated that a neutralizing MCP-1 antibody antagonized monocyte chemotaxis in the CSF of meningitis patients (Lahrtz et al., 1997) and migration of monocytes after HIV-1 Tat induction of MCP-1 in transmigration assays (Weiss et al., 1999).

Astrocytes are thought to be the predominant source of MCP-1 after a diverse array of CNS insults (Glabinski et al., 1996; Gourmala et al., 1997). In situ hybridization studies implicate astrocytes as the earliest and most predominant source of MCP-1 after implantation injury, stab injury (Glabinski et al., 1996), and ischemic or inflammatory insult (Gourmala et al., 1997). Although a wealth of evidence exists supporting the role of astrocytes in MCP-1 expression and recruitment of hematogenous cells to the site of injury, the signals that initiate chemokine expression in astrocytes have not been determined.

We investigated the role for extracellular ATP because, under several conditions in which MCP-1 expression increases, the concentration of extracellular ATP also rises. During the response to ischemia, extracellular ATP and other purines increase up to 200-fold (Rudolfi, 1994), and trauma presumably would produce even higher levels because the intracellular ATP pool (3-5 mM) spills out onto surrounding cells.

Extracellular ATP exerts biological effects by acting on cell surface P2-purinergic receptors. Purinergic receptors are divided into two major subclasses, P2Y, which are G-protein-linked, and P2X, which are ligand-gated ion channels (Chen et al., 1995). The $\mathrm{P} 2 \mathrm{X} 7$ receptor is the newest member of the P2X family. Initially thought to exist only on cells of the immune system, the P2X7 receptor is now known to have a wider distribution. Using immunocytochemistry, we localized the $\mathrm{P} 2 \mathrm{X} 7$ receptor to astrocytes both in cell culture and in astrocytes acutely isolated from the hippocampus (Fig. 1).

$\mathrm{P} 2 \mathrm{X} 7$ receptor signaling mechanisms have been studied infrequently, perhaps because the $\mathrm{P} 2 \mathrm{X} 7$ receptor carries no known 
a

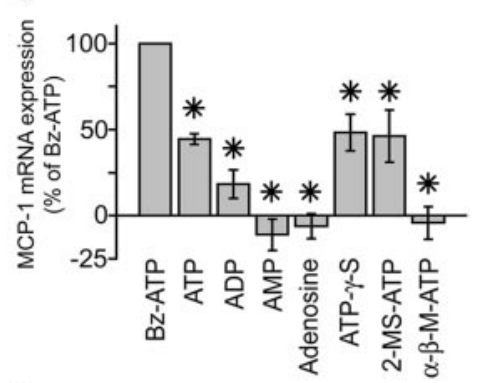

b
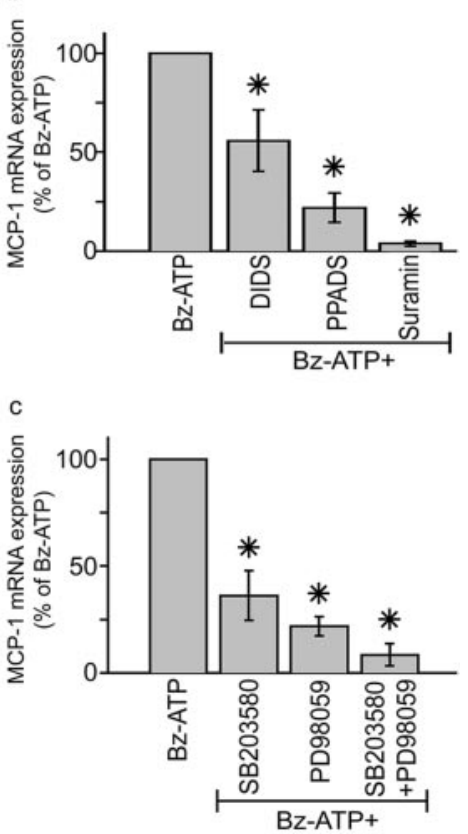

Figure 6. MCP-1 expression is induced by $\mathrm{P} 2 \mathrm{X} 7$ receptor activation and is blocked by ERK1/ERK2 and p38 inhibition. $a$, Purinergic agonists demonstrated a profile consistent with $\mathrm{P} 2 \mathrm{X} 7$ receptor-induced MCP-1 expression ( $A T P-\gamma-S$, adenosine 5'-O-[3-thiotriphosphate]; 2-MS-ATP, 2 -methylthio ATP; $\alpha$ - $\beta$-M-ATP, $\alpha$ - $\beta$-methylene ATP). The control level was the level of MCP-1 expression in untreated cultures and was defined as $0 \%$. The level of expression documented with the selective P2X7 agonist Bz-ATP was defined as $100 \%$. All compounds were applied at 100 $\mu \mathrm{M}$ for $2 \mathrm{hr}$. $b$, Purinergic receptor antagonists revealed a profile consistent with $\mathrm{P} 2 \mathrm{X} 7$ receptor involvement in MCP-1 expression. Bz-ATP (100 $\mu \mathrm{M})$ was applied to the cultures in the presence or absence of various signaling inhibitors ( $O-A T P$, oxidized ATP; $P P A D S$, pyridoxalphosphate6-azophenyl-2',4'-disulfonic acid; $D I D S, 4^{\prime} 4^{\prime}$ 'diisothiocyanatostilbene2,2'-disulfonic acid). Concentrations and preincubation times of inhibitors are the same as in Figure 2. $c$, The MAP kinases ERK1/ERK2 and p38 were involved in P2X7-induced MCP-1 expression. The specific ERK inhibitor PD98059 $(50 \mu \mathrm{M})$ and/or the specific p38 inhibitor SB203580 (25 $\mu \mathrm{M})$ reduced P2X7 receptor-induced MCP-1 signaling. Asterisks indicate a significant decrease from the Bz-ATP sample group.

signaling motif (Ferrari et al., 1997). We have established that both the ERK and p38 pathways are downstream signaling elements of $\mathrm{P} 2 \mathrm{X} 7$ receptor activation. P2X7-mediated stimulation of the ERKs is consistent with the mitogenic effects of ATP and with the known apoptotic function of the $\mathrm{P} 2 \mathrm{X} 7$ receptor. $\mathrm{P} 2 \mathrm{X} 7$ activation induces apoptosis in many cell types (Ferrari et al., 1999), and the MAP kinases, including ERK and p38, play central roles in the cascade to programmed cell death. In many cell types, including neurons, the commitment to apoptosis rests largely with the balance of activated p38 and ERK in the cell; activation of p38 correlates with apoptosis, whereas ERK activation is protec-
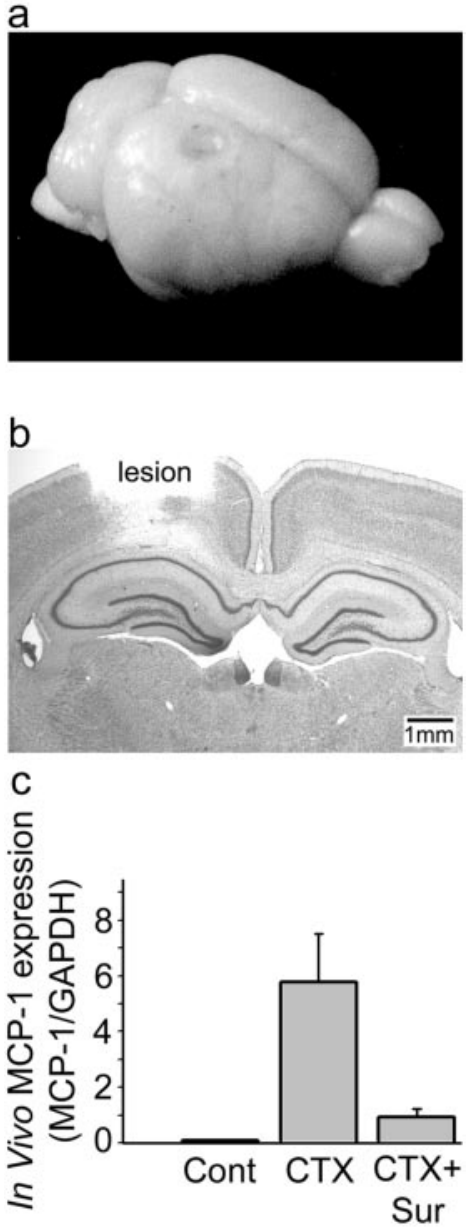

Figure 7. Inhibiting purinergic receptors depresses in vivo MCP-1 expression after trauma. $a$, Photograph of rat brain depicting site of corticectomy lesion. $b$, Cresyl violet $50 \mu \mathrm{m}$ coronal section of rat brain through the level of the corticectomy lesion. $c$, The purinergic receptor antagonist Suramin significantly reduced in vivo MCP-1 expression induced by corticectomy. After corticectomy, gelfoam containing either PBS/saline (control corticectomy, $C T X)$ or Suramin $(C T X+$ Sur $)(1 \mathrm{~mm})$ was inserted into the lesion site. Then, fluorescence-based real-time quantitation of MCP-1 transcripts was performed on tissue that was extracted from a defined area around the lesion site.

tive (Xia et al., 1995). Our finding of $\mathrm{p} 38$ induction in response to P2X7 stimulation may help to delineate the pathway whereby this purinergic receptor elicits cell death. The increase in ERK activity also presents a possible explanation as to why some cells are resistant to P2X7-mediated apoptosis (Di Virgilio et al., 1996).

Both the p38 and ERK pathways are involved in MCP-1 expression in cell culture. Our findings parallel recent results by Carter et al. (1999b) who demonstrated in alveolar macrophages that lipopolysaccharide induced tumor necrosis factor and interleukin-1 production was sensitive to both ERK and p38 pathways, and that combined inhibition reduced these cytokines to near control levels. p38 may exert its influence through NF- $\kappa-\mathrm{B}$, because p38 has recently been shown to be required for NF- $\kappa-\mathrm{B}$ dependent gene expression (Carter et al., 1999a) and the MCP-1 promoter has an NF- $\kappa$-B binding site (Martin et al., 1997). The involvement of the ERK pathway in MCP-1 expression is surprising, given that it was excluded as an essential component in MCP-1 expression in response to PDGF (Alberta et al., 1999). It is consistent, however, with the known variances in MCP-1 reg- 
ulation between cell types and in response to varied stimuli (Alberta et al., 1999).

Purinergic involvement in MCP-1 expression suggests an intriguing new role for extracellular ATP after CNS injury. In particular, we propose that ATP contributes to the infiltration of inflammatory hematogenous cells into the CNS, by mediating the induction of MCP-1. Given the promiscuous role of MCP-1 in disease, a role for purinoceptors may extend beyond trauma. For example, it has been known since 1985 that Suramin is protective in mouse models of experimental autoimmune encephalomyelitis (EAE) (van der Veen et al., 1985), although the mechanism is unknown. Our current results suggest that Suramin may suppress MCP-1 production and hence, slow the progression of EAE. It should be noted, however, that there are other actions of Suramin that may contribute to its action in vivo (Ralevic and Burnstock, 1998). Because purinergic receptor inhibitors are currently in common medical practice, our data raise the attractive possibility that these inhibitors may be of use in the treatment of neuroAIDS, multiple sclerosis, and other CNS disorders for which the pathogenesis includes induction of MCP-1.

\section{REFERENCES}

Alberta JA, Auger KR, Batt D, Iannarelli P, Hwang G, Elliott HL, Duke R, Roberts TM, Stiles CD (1999) Platelet-derived growth factor stimulation of monocyte chemoattractant protein-1 gene expression is mediated by transient activation of the phosphoinositide 3-kinase signal transduction pathway. J Biol Chem 274:31062-31067.

Balasingam V, Yong VW (1996) Attenuation of astroglial reactivity by interleukin-10. J Neurosci 16:2945-2955.

Ballerini P, Rathbone MP, Di Iorio P, Renzetti A, Giuliani P, D'Alimonte I, Trubiani O, Caciagli F, Ciccarelli R (1996) Rat astroglial P2Z (P2X7) receptors regulate intracellular calcium and purine release. NeuroReport 7:2533-2537.

Barnard EA, Simon J, Webb TE (1997) Nucleotide receptors in the nervous system. An abundant component using diverse transduction mechanisms. Mol Neurobiol 15:103-129.

Beigi RD, Dubyak GR (2000) Endotoxin activation of macrophages does not induce ATP release and autocrine stimulation of P2 nucleotide receptors. J Immunol 165:7189-7198.

Bell MD, Taub DD, Perry VH (1996) Overriding the brain's intrinsic resistance to leukocyte recruitment with intraparenchymal injections of recombinant chemokines. Neuroscience 74:283-292.

Berman JW, Guida MP, Warren J, Amat J, Brosnan CF (1996) Localization of monocyte chemoattractant peptide-1 expression in the central nervous system in experimental autoimmune encephalomyelitis and trauma in the rat. J Immunol 156:3017-3023.

Braun N, Zhu Y, Krieglstein J, Culmsee C, Zimmermann H (1998) Upregulation of the enzyme chain hydrolyzing extracellular ATP after transient forebrain ischemia in the rat. J Neurosci 18:4891-4900.

Carter AB, Knudtson KL, Monick MM, Hunninghake GW (1999a) The p38 mitogen-activated protein kinase is required for NF-kappaBdependent gene expression. The role of TATA-binding protein (TBP). J Biol Chem 274:30858-30863.

Carter AB, Monick MM, Hunninghake GW (1999b) Both Erk and p38 kinases are necessary for cytokine gene transcription. Am J Respir Cell Mol Biol 20:751-758.

Chen ZP, Levy A, Lightman SL (1995) Nucleotides as extracellular signalling molecules. J Neuroendocrinol 7:83-96.

Conant K, Garzino-Demo A, Nath A, McArthur JC, Halliday W, Power C, Gallo RC, Major EO (1998) Induction of monocyte chemoattractant protein-1 in HIV-1 Tat-stimulated astrocytes and elevation in AIDS dementia. Proc Natl Acad Sci USA 95:3117-3121.

Crepel V, Panenka W, Kelly ME, MacVicar BA (1998) Mitogenactivated protein and tyrosine kinases in the activation of astrocyte volume-activated chloride current. J Neurosci 18:1196-1206.

Di Virgilio F, Ferrari D, Falzoni S, Chiozzi P, Munerati M, Steinberg TH, Baricordi OR (1996) P2 purinoceptors in the immune system. Ciba Found Symp 198:290-302.

el-Moatassim C, Dubyak GR (1993) Dissociation of the pore-forming and phospholipase D activities stimulated via $\mathrm{P} 2 \mathrm{z}$ purinergic receptors in BAC1.2F5 macrophages. Product inhibition of phospholipase D enzyme activity. J Biol Chem 268:15571-15578.

Ferrari D, Wesselborg S, Bauer MKA, Schulze-Osthoff K (1997) Extracellular ATP activates transcription factor NF-kappaB through the P2Z purinoreceptor by selectively targeting NF-kappaB p65. J Cell Biol 139:1635-1643.

Ferrari D, Los M, Bauer MK, Vandenabeele P, Wesselborg S, Schulze-
Osthoff K (1999) P2Z purinoreceptor ligation induces activation of caspases with distinct roles in apoptotic and necrotic alterations of cell death. FEBS Lett 447:71-75.

Fraser DD, Duffy S, Angelides KJ, Perez-Velazquez JL, Kettenmann H, MacVicar BA (1995) GABAA/benzodiazepine receptors in acutely isolated hippocampal astrocytes. J Neurosci 15:2720-2732.

Fuentes ME, Durham SK, Swerdel MR, Lewin AC, Barton DS, Megill JR, Bravo R, Lira SA (1995) Controlled recruitment of monocytes and macrophages to specific organs through transgenic expression of monocyte chemoattractant protein-1. J Immunol 155:5769-5776.

Glabinski AR, Balasingam V, Tani M, Kunkel SL, Strieter RM, Yong VW, Ransohoff RM (1996) Chemokine monocyte chemoattractant protein-1 is expressed by astrocytes after mechanical injury to the brain. J Immunol 156:4363-4368.

Gosling J, Slaymaker S, Gu L, Tseng S, Zlot CH, Young SG, Rollins BJ, Charo IF (1999) MCP-1 deficiency reduces susceptibility to atherosclerosis in mice that overexpress human apolipoprotein B. J Clin Invest 103:773-778.

Gourmala NG, Buttini M, Limonta S, Sauter A, Boddeke HW (1997) Differential and time-dependent expression of monocyte chemoattractant protein-1 mRNA by astrocytes and macrophages in rat brain: effects of ischemia and peripheral lipopolysaccharide administration. J Neuroimmunol 74:35-44.

Gu L, Okada Y, Clinton SK, Gerard C, Sukhova GK, Libby P, Rollins BJ (1998) Absence of monocyte chemoattractant protein-1 reduces atherosclerosis in low density lipoprotein receptor-deficient mice. Mol Cell 2:275-281.

Heasley LE, Johnson GL (1992) The beta-PDGF receptor induces neuronal differentiation of PC12 cells. Mol Biol Cell 3:545-553.

Ivacko J, Szaflarski J, Malinak C, Flory C, Warren JS, Silverstein FS (1997) Hypoxic-ischemic injury induces monocyte chemoattractant protein-1 expression in neonatal rat brain. J Cereb Blood Flow Metab 17:759-770.

Kennedy KJ, Strieter RM, Kunkel SL, Lukacs NW, Karpus WJ (1998) Acute and relapsing experimental autoimmune encephalomyelitis are regulated by differential expression of the CC chemokines macrophage inflammatory protein-1alpha and monocyte chemotactic protein-1. J Neuroimmunol 92:98-108.

Lahrtz F, Piali L, Nadal D, Pfister HW, Spanaus KS, Baggiolini M, Fontana A (1997) Chemotactic activity on mononuclear cells in the cerebrospinal fluid of patients with viral meningitis is mediated by interferon-gamma inducible protein-10 and monocyte chemotactic protein-1. Eur J Immunol 27:2484-2489.

Lammas DA, Stober C, Harvey CJ, Kendrick N, Panchalingam S, Kumararatne DS (1997) ATP-induced killing of mycobacteria by human macrophages is mediated by purinergic $\mathrm{P} 2 \mathrm{Z}(\mathrm{P} 2 \mathrm{X} 7)$ receptors. Immunity 7:433-444.

Lassmann H (1997) Basic mechanisms of brain inflammation. J Neural Transm [Suppl] 50:183-190.

MacVicar BA, Hochman D, Delay MJ, Weiss S (1991) Modulation of intracellular $\mathrm{Ca}++$ in cultured astrocytes by influx through voltageactivated $\mathrm{Ca}++$ channels. Glia 4:448-455.

Martin T, Cardarelli PM, Parry GC, Felts KA, Cobb RR (1997) Cytokine induction of monocyte chemoattractant protein-1 gene expression in human endothelial cells depends on the cooperative action of NFkappa B and AP-1. Eur J Immunol 27:1091-1097.

McManus C, Berman JW, Brett FM, Staunton H, Farrell M, Brosnan CF (1998) MCP-1, MCP-2 and MCP-3 expression in multiple sclerosis lesions: an immunohistochemical and in situ hybridization study. J Neuroimmunol 86:20-29.

McTigue DM, Tani M, Krivacic K, Chernosky A, Kelner GS, Maciejewski D, Maki R, Ransohoff RM, Stokes BT (1998) Selective chemokine mRNA accumulation in the rat spinal cord after contusion injury. J Neurosci Res 53:368-376.

Merrill JE, Kutsunai S, Mohlstrom C, Hofman F, Groopman J, Golde DW (1984) Proliferation of astroglia and oligodendroglia in response to human T cell-derived factors. Science 224:1428-1430.

Murgia M, Hanau S, Pizzo P, Rippa M, Di Virgilio F (1993) Oxidized ATP. An irreversible inhibitor of the macrophage purinergic P2Z receptor. J Biol Chem 268:8199-8203.

Neary JT, Zhu Q (1994) Signaling by ATP receptors in astrocytes. NeuroReport 5:1617-1620.

North RA, Barnard EA (1997) Nucleotide receptors. Curr Opin Neurobiol 7:346-357.

Pannicke T, Fischer W, Biedermann B, Schadlich H, Grosche J, Faude F, Wiedemann P, Allgaier C, Illes P, Burnstock G, Reichenbach A (2000) $\mathrm{P} 2 \mathrm{X} 7$ receptors in Muller glial cells from the human retina. J Neurosci 20:5965-5972.

Ralevic V, Burnstock G (1998) Receptors for purines and pyrimidines. Pharmacol Rev 50:413-492.

Ransohoff RM, Tani M (1998) Do chemokines mediate leukocyte recruitment in post-traumatic CNS inflammation? Trends Neurosci 21: 154-159. 
Rollins BJ (1996) Monocyte chemoattractant protein 1: a potential regulator of monocyte recruitment in inflammatory disease. Mol Med Today 2:198-204.

Rudolfi KA (1994) Adenosine and adenine nucleotides as regulators of cellular function (Phillips JW, ed), pp 423-432. Boca Raton, FL: CRC.

Schreiber FC, Krivacic K, Kirby B, Vaccariello SA, Wei T, Ransohoff RM, Zigmond RE (2001) Monocyte chemoattractant protein (MCP)-1 is rapidly expressed by sympathetic ganglion neurons following axonal injury. NeuroReport 12:601-606.

Simpson JE, Newcombe J, Cuzner ML, Woodroofe MN (1998) Expression of monocyte chemoattractant protein-1 and other betachemokines by resident glia and inflammatory cells in multiple sclerosis lesions. J Neuroimmunol 84:238-249.

Surprenant A, Rassendren F, Kawashima E, North RA, Buell G (1996) The cytolytic P2Z receptor for extracellular ATP identified as a P2X receptor (P2X7). Science 272:735-738.

Swanson KD, Reigh C, Landreth GE (1998) ATP-stimulated activation of the mitogen-activated protein kinases through ionotrophic P2X2 purinoreceptors in PC12 cells. Difference in purinoreceptor sensitivity in two PC12 cell lines. J Biol Chem 273:19965-19971.

Tse FW, Fraser DD, Duffy S, MacVicar BA (1992) Voltage-activated $\mathrm{K}+$ currents in acutely isolated hippocampal astrocytes. J Neurosci 12:1781-1788.

van der Veen RC, Asghar SS, Uitdehaag BM, van der Helm HJ, Hommes
OR (1985) Suppression of the development of experimental allergic encephalomyelitis by suramin. Neuropharmacology 24:1139-1142.

Wang X, Yue TL, Barone FC, Feuerstein GZ (1995) Monocyte chemoattractant protein-1 messenger RNA expression in rat ischemic cortex. Stroke 26:661-665.

Watson SP, Girdlestone D (1996) Receptor and ion channel nomenclature supplement. Trends Pharmacol Sci [Suppl S]:1-81.

Weiss JM, Nath A, Major EO, Berman JW (1999) HIV-1 Tat induces monocyte chemoattractant protein-1-mediated monocyte transmigration across a model of the human blood-brain barrier and up-regulates CCR5 expression on human monocytes. J Immunol 163:2953-2959.

Wiley JS, Chen R, Jamieson GP (1993) The ATP4-receptor-operated channel (P2Z class) of human lymphocytes allows Ba2+ and ethidium + uptake: inhibition of fluxes by suramin. Arch Biochem Biophys 305:54-60.

Winston BW, Riches DW (1995) Activation of p42mapk/erk2 following engagement of tumor necrosis factor receptor CD120a (p55) in mouse macrophages. J Immunol 155:1525-1533.

Xia Z, Dickens M, Raingeaud J, Davis RJ, Greenberg ME (1995) Opposing effects of ERK and JNK-p38 MAP kinases on apoptosis. Science 270:1326-1331.

Yamagami S, Tamura M, Hayashi M, Endo N, Tanabe H, Katsuura Y, Komoriya K (1999) Differential production of MCP-1 and cytokineinduced neutrophil chemoattractant in the ischemic brain after transient focal ischemia in rats. J Leukoc Biol 65:744-749. 